\title{
Diagnosis of Staphylococcus aureus intramammary infections by detecting antibodies in milk with an ELISA kit
}

\author{
B Poutrel, P Sarradin \\ Laboratoire de Pathologie Infectieuse et d'Immunologie, INRA, 37380 Nouzilly, France
}

(Received 14 November 1991; accepted 30 January 1992)

\begin{abstract}
Summary - An enzyme-linked immunosorbent assay (ELISA) for detecting Staphylococcus aureus antibodies in bovine milk samples and developed to differentiate infected from uninfected cows was evaluated by comparison with bacteriological examination. Thirty-two lactating cows from 3 dairy herds were selected on the basis of the pathogens isolated from their milk with confirmed culture at a second sampling. When compared to culture results considered as the reference, the accuracy of the ELISA test was $87.5 \%$ and showed an agreement of $89.5 \%$ and $84.6 \%$ for negative and positive samples respectively. For $S$ aureus infected cows, there was no correlation between somatic cell counts and reactivity of composite milk samples to the exoantigens used in the ELISA. Neither was there any apparent relationship between numbers of infected quarters per cow and optical density values.
\end{abstract}

Staphylococcus aureus / mastitis / ELISA

Résumé - Diagnostic des infections mammaires à Staphylococcus aureus par détection des anticorps dans le lait à l'aide d'un kit ELISA. Un test ELISA, basé sur la détection d'anticorps dans le lait, et développé pour identifier les vaches ayant des infections mammaires à Staphylococcus aureus, a été évalué par comparaison au diagnostic bactériologique. En prenant en considération les résultats des analyses bactériologiques, 32 vaches provenant de 3 troupeaux laitiers ont été retenues pour cette étude. Estimée par rapport aux cultures bactériologiques, l'exactitude du test ELISA est de $87,5 \%$ avec une concordance de $89,5 \%$ et $84,6 \%$ respectivement pour les échantillons de lait négatifs ou positifs. Aucune corrélation n'a pu être établie entre les résultats du test ELISA et la numération des cellules somatiques des vaches infectées par $S$ aureus ou le nombre de quartiers infectés par vache.

Staphylococcus aureus / mammite / ELISA

\section{INTRODUCTION}

Subclinical mastitis can affect quarters up to 50 times more than clinical mastitis (Bramley and Dodd, 1984). Staphylococcus aureus is the most common pathogen causing bovine chronic subclinical mastitis. The primary sources of this pathogen are infected mammary glands, teat lesions and colonised teat ducts. Bacteria are readily transferred between teats and cows during milking. $S$ aureus cannot be eradicated from the herd by anti-microbial therapy (Le Louedec, 1978; Dodd, 1983). Consequently, culling and segregation of infected cows are useful to control bacte- 
rial transmission and to eradicate $S$ aureus from a dairy herd. Specific detection methods are needed to optimize these control measures. The culture and bacterial examination of milk samples to identify the microbial pathogen is slow and costly. An additional problem of bacterial culture is the requirement of an aseptically collected milk sample. Recently, an enzyme-linked immunosorbent assay (ELISA) was developed to identify cows with $S$ aureus intramammary infections by detecting specific antibody to staphylococcal exoproteins in milk (Adams et al, 1988). The ELISA kit can be used on unpreserved or chemically preserved milk and does not require an aseptic collection of milk. Results can be obtained in about $1 \mathrm{~h}$ by visual comparison with both negative and positive controls, or alternatively a spectrophotometric ELISA plate reader can be used.

The work presented here describes a preliminary evaluation of the ability of the commercial kit to differentiate $S$ aureus infected cows from uninfected cows by comparing bacteriological results and ELISA.

\section{MATERIALS AND METHODS}

\section{Herds and milk samples}

Foremilk samples from all quarters were collected aseptically to determine existing intramammary infections in 3 herds consisting of 190 lactating cows. To avoid collecting samples containing blood-derived $S$ aureus antibodies from cows which did not have active intramammary infections, only cows which had exceeded 30 days lactation after calving were included in this study (Adams et al, 1988). Additional foremilk samples were collected aseptically 1-3 weeks later and 32 cows were selected on the basis of the confirmation of the presence of previous isolated microorganisms.

Somatic cell counts (SCC) and ELISA were performed on composite foremilk samples ob- tained by mixing $0.8 \mathrm{ml}$ of each quarter sample from each cow.

\section{Bacteriological examination and somatic cell counts}

A $0.025-\mathrm{ml}$ sample of each quarter milk sample was plated on aesculin sheep blood agar medium. All the cultures were incubated aerobically for $24-48 \mathrm{~h}$ at $37^{\circ} \mathrm{C}$ before being examined for the identification of bacterial colonies. SCC were determined by use of a Coulter counter as recommended by the International Dairy Federation (1984).

\section{Enzyme-linked immunosorbent assay}

The ELISA was performed as indicated in the manufacturer's instructions (ProStaph I, ProScience Corp, Sterling VA, USA).

Each composite sample and positive and negative controls were assayed in duplicate. The optical density (OD) at $405 \mathrm{~nm}$ was read with an automated microplate reader. A positive ELISA result was defined as any $O D$ equal to or greater than the positive control. A sample with an OD value less than $85 \%$ of the positive control was classified negative, and suspect when the OD values was $85-100 \%$ of the positive control.

\section{RESULTS}

According to bacterial culture results, samples were divided into groups lettered from A to $E$ (table I).

Composite samples from cows with either non infected quarters (group A) or quarters infected by coagulase-negative staphylococci (group B) had the lowest values for SCC and ELISA tests. For cows with one or more quarters infected by $S$ aureus (groups D and E), there was no correlation $(r=0.16)$ between SCC and ELISA values. 
Table I. Relationship between either infection status of the mammary gland or somatic cell counts and ELISA values.

Relations entre le statut infectieux des mamelles ou le nombre de cellules somatiques du lait avec les valeurS ELISA.

\begin{tabular}{|c|c|c|c|c|c|c|}
\hline \multirow[t]{2}{*}{ Groups } & \multirow[t]{2}{*}{$\begin{array}{c}\text { No } \\
\text { of cows }\end{array}$} & \multirow[t]{2}{*}{ Pathogens isolated a } & \multicolumn{2}{|c|}{$\begin{array}{l}\text { Somatic cell counts }{ }^{b} \\
\left(\times 10^{3} / \mathrm{ml}\right)\end{array}$} & \multicolumn{2}{|c|}{$E L I S A^{b}(O D)$} \\
\hline & & & Mean & Range & Mean & Range \\
\hline A & 6 & None & 191 & $160-263$ & 0.103 & $0.030-0.314$ \\
\hline B & 7 & Staph coagulase negative & 272 & $180-313$ & 0.115 & $0.047-0.404$ \\
\hline C & 6 & $\begin{array}{l}\text { Major pathogens } \\
\text { except } S \text { aureus }\end{array}$ & 1362 & $316-2883$ & 0.308 & $0.062-0.550$ \\
\hline D & 8 & $S$ aureus $+C$ bovis $d$ & 2640 & $519-5146$ & 0.537 & $0.107-1.102$ \\
\hline$E$ & 5 & $S$ aureus + Str uberis & 3764 & $3095-5554$ & 0.883 & $0.490-1.934$ \\
\hline
\end{tabular}

a Pathogens isolated from the different milk quarter samples of each cow. ${ }^{b}$ Values recorded from composite samples from each cow. Value for positive control in ELISA was 0.397. ' Major pathogens isolated were $E$ coli, Str uberis, Enterococcus faecalis, Enterococcus faecium, Str bovis. ${ }^{\circledR}$ Only one cow without $C$ bovis infection.

Comparison between culture and ELISA results is shown in table II. None of the samples was classified as suspect by ELISA test. An agreement of $89.5 \%$ and

Table II. Comparison of ELISA reactivity and bacteriological results.

Comparaison entre les résultats obtenus en ELISA et les cultures bactériologiques.

\begin{tabular}{lrrr}
$\begin{array}{l}\text { S aureus culture a } \\
\end{array}$ & \multicolumn{3}{c}{$\begin{array}{c}\text { ELISA }{ }^{b} \text { classification } \\
\text { (No of samples) }\end{array}$} \\
\cline { 2 - 4 } & Positive & Negative & Total \\
\hline Positive & 11 & 2 & 13 \\
Negative & 2 & 17 & 19 \\
\hline
\end{tabular}

a Culture of quarter milk samples. ${ }^{b}$ ELISA for milk antibody to $S$ aureus was performed on composite milk samples.
$84.6 \%$ was recorded for culture negative samples and culture positive samples respectively. Two quarter milk samples were found positive by culture for $S$ aureus and the corresponding composite cow milk samples negative by ELISA for antibody. The SCC values for these samples were 519000 and $1906000 / \mathrm{ml}$. Of the 2 samples from cows infected with an organism other than $S$ aureus classified positive on the ELISA, SCC's were 393000 and $2883000 / \mathrm{ml}$. Culture results on these samples were respectively 2 coagulasenegative staphylococci (2 quarters infected) and 1 Escherichia coli with 3 Corynebacterium bovis ( 4 quarters infected). As indicated in table III, there was no apparent relationship between the number of quarters infected by $S$ aureus for each cow and the $O D$ values recorded for composite samples in the ELISA test. 
Table III. Relationship between the number of quarters infected by $S$ aureus and the ELISA reactivity of composite milk samples.

Relation entre le nombre de quartiers infectés par $S$ aureus et les valeurs obtenues en ELISA sur le lait de mélange de chaque vache.

\begin{tabular}{ccc}
\hline $\begin{array}{c}\text { No of } \\
\text { quarters per cow }\end{array}$ & $\begin{array}{c}\text { No of } \\
\text { infected cows }\end{array}$ & $\begin{array}{c}\text { Optical density } \\
\text { (mean) }\end{array}$ \\
\hline & 10 & 0.609 \\
2 & 1 & 1.934 \\
3 & 2 & 0.615 \\
\hline
\end{tabular}

\section{DISCUSSION}

The accuracy of the ELISA test used herein, defined as the ability of the assay to give correct results relative to bacterial culture, was $87.5 \%$. The specificity and the sensitivity which are the ability of the ELISA test to identify true negative and true positive samples was $89.5 \%$ and $84.6 \%$ respectively. These percentages were slightly less than those previously reported (Matsushita et al, 1990).

The 2 ELISA false negative reactions found in the $13 \mathrm{~S}$ aureus culture positive samples may indicate either infections not involving the gland itself but restricted to the teat canal or existence of infections which had not been present long enough to promote detectable antibody. As these samples remained culture positive upon resampling and had SCC of over 500000 / $\mathrm{ml}$, the first hypothesis can reasonably be set aside.

Although most intramammary infections are persistent and spontaneous cure is not frequent (Rainard and Poutrel, 1982), the 2 samples which were found to be negative for culture of $S$ aureus but positive by ELISA could be explained by intermittent shedding of $S$ aureus or presence of anti- bodies resulting from a previous spontaneously-cured staphylococcal infection.

Also false positive results in ELISA may have resulted from either cross-reactivity with antigens of other microorganisms or leakage of antibodies into the milk compartment promoted by inflammation. Indeed, these samples were cultured positive for coagulase-negative staphylococci and Escherichia coli associated with Corynebacterium bovis. Lack of reactivity to the $S$ aureus antigens of milk samples from most cows infected by coagulase-negative staphylococci (group B) and other major pathogens (group C) is in favour of the specificity to exoantigens selected in the ELISA test (Adams et al, 1988). The exudation of immunoglobulins from the blood into the milk compartment which occurs during acute infections, for example $E$ coli and Streptococcus uberis infections, could explain the presence in the milk of naturally acquired antibodies to $S$ aureus antigens. The limited number of samples with this type of infection does not allow us to draw a conclusion on this point. However, the lack of correlation between SCC and $O D$ values previously reported for infections caused by microorganisms other than $S$ aureus (Adams et al, 1988) and confirmed in this study for staphylococcal infections suggests that inflammation alone is not likely to be a major cause of false positive reactions in the ELISA test and that antibodies to $S$ aureus exoantigens may be mainly produced in the mammary gland.

Most of the staphylococcal infections were correctly diagnosed from composite milk samples although the majority of $S$ aureus infections were established solely in one quarter of each cow, as shown in table III. This and the lack of correlation between the OD values in ELISA recorded on composite milk samples and the number of quarters from each cow infected by 
$S$ aureus indicate that the limit of detection of the ELISA test used was good enough to be apparently unaffected by dilution of antibodies.

The diagnosis of subclinical mastitis is usually based on identifying pathogens isolated from aseptically taken milk samples, and by measuring the effects of the inflammation on the milk. Errors occur because pathogens are not always isolated from infected quarters, milk samples can be contaminated, and the extent of the inflammation is variable. Concerning $S$ aureus infections, our results confirm that the disagreement between bacterial culture and ELISA antibody test is minimal, as previously reported (Matsushita et al, 1990). Taking into account the different causes of false negative and false positive results, it is likely that the number of discordant results should be lowered by additional testing.

In conclusion, the ELISA test used in this study is accurate in differentiating $S$ aureus-infected from uninfected cows. The test is fast and can be performed either on chemically preserved or fresh milk and does not require aseptic collection. It is therefore suitable for the screening of large numbers of samples and offers a useful diagnostic tool to the dairy farmer and the veterinarian for implementing a mastitis control strategy.

\section{ACKNOWLEDGMENTS}

This work was supported by Laboratoire Sogeval (Laval, France). The authors wish to thank $M$ Ducelliez for technical assistance and P Rainard for his critical review of the manuscript.

\section{REFERENCES}

Adams DS, McDonald JS, Hancock D, McGuire TC (1988) Staphylococcus aureus antigens reactive with milk immunoglobulins $\mathrm{G}$ of naturally infected dairy cows. J Clin Microbiol 26, 1175-1180

Bramley AJ, Dodd FH (1984) Reviews of the progress of dairy science: mastitis control progress and prospects. J Dairy Res 51,481 512

Dodd FH (1983) Mastitis: progress on control. J Dairy Sci 66, 1773-1780

International Dairy Federation (1984) Recommended Methods for Somatic Cell Counting in Milk. Doc 168, Brussels, Belgium

Le Louedec C (1978) Efficacité des antibiotiques contre les mammites bovines staphylococciques et streptococciques. Revue bibliographique. Ann Rech Vét 9, 63-88

Matsushita T, Dinsmore RP, Eberhart RJ, Jones GM, McDonald JS, Sears PM, Adams DS (1990) Performance studies of an enzymelinked immunosorbent assay for detecting Staphylococcus aureus antibody in milk. $J$ Vet Diagn Invest 2, 163-166

Rainard P, Poutrel B (1982) Dynamics of nonclinical bovine intramammary infections with major and minor pathogens. Am J Vet Res $43,2143-2146$ 